Fontana LB, Grugel J. Deviant and Hyper-Compliance: The Domestic Politics of Child Labor in Bolivia and Argentina. Human Rights Quarterly 2017, 39(3), 631656.

DOI link

https://doi.org/10.1353/hrq.2017.0035

ePrints link

http://eprint.ncl.ac.uk/pub details2.aspx?pub id $=245228$

Date deposited

$16 / 01 / 2018$

Copyright

C 2017 by Johns Hopkins University Press

This is the authors' accepted manuscript of an article that has been published in its final definitive form by John Hopkins University Press, 2017. 


\title{
Deviant and Over-compliance: The Domestic Politics of Child Labor in Bolivia and Argentina ${ }^{1}$
}

\author{
Lorenza B. Fontana ${ }^{2}$ and Jean Grugel $l^{3}$
}

\begin{abstract}
This article explores the reception of human rights norms on child labour in Bolivia and Argentina, countries where governments and civil societies express support for human rights. Yet national responses after ratification of International Labor Organization's conventions diverge significantly. In Bolivia domestic interpretations of human rights have prevailed over attachment to ILO conventions ('deviant compliance') while in Argentina national policies exceed ILO recommendations ('over-compliance'). We use the evidence presented here to call for a more nuanced understanding of what compliance with human rights principles is understood to mean and to stress the importance of domestic interpretations of international norms.
\end{abstract}

Keywords: Compliance Politics, Child Labor, Human Rights, ILO, Latin America, Bolivia, Argentina

\footnotetext{
${ }^{1}$ Copyright (C) 2017 Johns Hopkins Univeristy Press. To cite this article: Fontana, Lorenza B., and Jean Grugel. "Deviant and Over-Compliance: The Domestic Politics of Child Labor in Bolivia and Argentina." Human Rights Quarterly 39.3 (2017): 631-656.

${ }^{2}$ Marie Curie Research Fellow, Weatherhead Center for International Affairs, Harvard University, lorenza_fontana@fas.harvard.edu

${ }^{3}$ Professor of Global Politics, Department of Politics, University of York, j.b.grugel@gmail.com
} 
International human rights agreements have proliferated since the 1990s. ${ }^{1}$ They seek to encourage states to behave in ways that respect human rights and they play a major role in shaping ideas about how world politics should be conducted. Indeed, the influence of human rights agreements is now such that it is even felt in the domestic politics of non-democracies. ${ }^{2}$ But despite their proliferation, we still have an incomplete understanding of how states respond to internationally agreed charters of rights, why they respond how they do, the circumstances under which rights treaties make a difference and what that difference might be. Simmons ${ }^{3}$ and others ${ }^{4}$ argue that attention should be paid to national-level politics in explaining state responses. Legal changes after ratification are more likely to occur when key domestic actors, whether from within the state or civil society or a mix of both, recognise the value of the international norm and pressurize for rights-based policies.

Compliance tends to be understood in this debate in an either/or fashion: state either come into line with international human rights law or not. As Chayes and Chayes put it, the question is whether there is "observance (or not) of treaty commitments by the parties". 5 This understanding prevails not only in international law scholarship but also in international relations. ${ }^{6}$ Legal anthropology and constructivist approaches to international relations sought to document the 'translation' or 'socialization' of human rights that shapes domestic compliance, ${ }^{7}$ by which they mean how international norms become attached to local issues that allow communities to 'make sense' of the norm; but they have not challenged the assumption that 'compliance' implies an alignment between domestic practices and international agreements. Yet, in fact, treaty compliance and compliance with human rights principles are not necessarily identical. Treaties and agreements offer an interpretation of the underlying rights principles. There might be widespread acceptance of that interpretation; but equally, it is also possible to agree with the rights principle that inspired the norm, but not accept the way it has been codified. Indeed, it is also possible to hold the view that the international norm is too weak or does not go far enough.

What happens when governments accept the underlying rights principle associated with an international rights norm but disagree with its codification? Will they take steps to implement the international agreement or will they promote an alternative interpretation of the underlying rights principle that is thought to more adequately reflect domestic views? If governments choose the latter, we argue this can be understood as a form of 'deviant compliance', providing that there is a genuine engagement with internationally accepted human rights principles. Equally, governments might accept the rightness of both the international agreement and the underlying principles with such enthusiasm that their response goes significantly beyond that required under international law. We term this 'overcompliance $^{8}$. Both deviant and over-compliance are different from the expected shape compliance is traditionally thought to take, that is the close alignment of domestic law and practices with international norms. In fact, this traditional mode of compliance might more accurately be described as 'responsive compliance' since it implies a responsive reform of domestic practices following the ratification of international rights agreements.

We discuss the phenomenon of deviant and over-compliance here in relation to a set of international norms that seek to exclude children and young people from the labor market until they reach a certain age, usually 14 , and protect them from hazardous work. We draw on two examples from Latin America, Bolivia and Argentina. In both countries, international 
child labor norms and children's rights are taken seriously and there is acceptance of the rightness of human rights as a guiding principle of policy-making. Yet, in Bolivia, a national debate about children's rights and child labor led to a new law in 2014 that legalizes children working from the age of ten in some circumstances such as self-employment. There can be little doubt that Bolivian legislation is in contravention of International Labor Organization (ILO) policy, specifically Convention 138 (C.138) on the minimum age for work; nevertheless, the government and key civil society actors insist that the law is designed to protect child workers and uphold their rights. It is, in other words, a form of 'deviant compliance'. Argentina, meanwhile, not only seeks to uphold C.138 but has gone significantly beyond what is required to be legally compliant with ILO Convention 182 (C.182) on exploitative and inappropriate child labor, introducing legislation that punishes those who employ children with up to four years of prison. This, we argue, is an example of 'over-compliance'. The explanation for these responses lies in the structure of national politics and, in particular, domestic human rights politics. We thus follow Simmons 2009 and Grugel and Peruzzotti ${ }^{9}$ in stressing the importance of domestic politics for compliance, but, at the same time, we pay closer attention than they do to the spectrum of what compliance itself can be said to entail and emphasize the importance of domestic interpretations of human rights discourses for explaining compliance outcomes.

\section{Cases and Methods}

\section{Why Child Labor?}

Child labor is an important window into debates about compliance with human rights. On the one hand, the issue is becoming more salient in global politics thanks in part to pressures from international organizations (in particular the ILO and the United Nations Children's Fund, UNICEF) and non-governmental organizations such as Save the Children, Terre des Hommes, Defence of Children International. The elimination of child labor has been included as a target within the new Sustainable Development Goals, which has replaced the Millennium Development Goals (MDGs) in 2015 as the new global development roadmap. On the other hand, child labor brings together two issue-areas where there are growing pressures for the adoption of global rights-based standards: childhood and labor. Yet, perhaps surprisingly, child labor has been framed in terms of human rights only relatively recently. The study of child labor has been dominated in disciplinary terms mainly by economists, who tend to link it with particular household economies, capitalist and non-capitalist, and global chains of production, ${ }^{10}$ along with anthropological and sociological perspectives, which have sought instead to show how child work is culturally embedded and forms part of family practices of social reproduction. ${ }^{11}$ There are surprisingly few studies of child labor from a human rights perspective. ${ }^{12}$ The domestic politics of compliance in relation to child labor thus represents new terrain for human rights researchers. At the same time, it is gradually becoming clear to international policy makers that there are domestic dynamics to compliance with international child labor agreements which raise important questions for how they can pursue their own agenda: 
National and regional approaches are very important. In the end, it should be determined by the countries what particular responses they should put forward to face the problems that they experience. These problems are quite different and depend, for instance, on the types of child labor, the quality of the education and child protection system, or the strength of national governments. ${ }^{13}$

Understanding domestic debates around child labor is thus crucial both for academic debate and for global policy.

The ILO is at the forefront of attempts to reframe child labor from a human rights perspective. ${ }^{14}$ The organization has opposed child labor since its foundation in 1919 and set out minimum age for work in 1973 (C.138), but it was not until the 1990s that there was a decision to undertake a major push on child labor and, at the same time, a human rights focus crept into its work. In 1992, the ILO set up the International Programme on the Elimination of Child Labor (IPEC) to target certain states and offer both resources and pressure to reduce the numbers of working children. In 1998 the effective elimination of child labor was set out as one of the ILO's four 'fundamental principles'. C.182 came shortly after in 1999, specifically focusing on the elimination of the 'worst forms' of child labor, and was rapidly ratified. In 2002 an annual World Day against Child Labor was set up as a major ILO campaign, and ratifications of C.138 on the minimum age, which had been slow, eventually gathered pace. A new stage in ILO activity began in 2010 that explicitly linked the eradication of child labor to children's rights, leading to the international agreement (known as the Hague Roadmap) in the same year, signed by 97 countries, to eliminate the worst forms of child labor by 2016. ${ }^{15}$ This was followed by the Brasilia Declaration in 2013, which was a joint initiative of the ILO, governments and international Non Governmental Organizations (NGOs), to encourage states to take action on C.182.

Whilst C.182 is an independent agreement, referring specifically and only to the worst forms of child labor, it is, in fact, closely bound up with the ILO's push against all forms of child labor - and understood as such within the ILO itself and in countries targeted for action. This link is often highlighted in ILO documents including its guide to C.182:

The basis of such action [to eliminate child labor] must be legislation, which keeps the total elimination of child labor as the ultimate goal of policy, but which explicitly identifies and prohibits the worst forms of child labor to be eliminated as a matter of priority. ${ }^{16}$

This means that national policies in response to C.182 often deal with the issue of child labor more widely; pressure to implement C.182 has, in effect, opened up a broader discussion of whether children should work at all and whether work in any form is an intrinsic violation of their rights. In fact, while the idea that children have distinctive agerelated human rights is accepted by most states (as set out in the widely ratified United Nations Convention on the Rights of the Child, UNCRC, 1989), the view that children's rights are best protected by the elimination of child labor is more contentious. ${ }^{17}$ Labor and production practices are profoundly shaped by deep, place-based traditions of production and social reproduction, which mean that children in many parts of the world contribute significantly to family income. ${ }^{18}$ As such, child labor often takes place in cultural contexts 
that do not consider it as necessarily bad for children. It was almost inevitable, therefore, that the ILO decision to incorporate the elimination of child labor as one of its fundamental principles (1998) was bound to be controversial in countries where child labor is profoundly embedded in household economies and local culture. ${ }^{19}$

Yet despite the fact that the nexus between human rights and child labor is contentious terrain, there are as yet few detailed studies on domestic policy responses to ILO agreements in contexts where significant numbers of children work, whether formally or informally. Logically, given the social embeddness and economic significance of children's work for many households and families in the global South, what compliance with international rights agreements comes to mean here will yield some important insights into both the social construction of compliance itself and the domestic politics that underpins different national approaches.

\section{Why Bolivia and Argentina?}

Latin America is increasingly recognized as a 'right-respecting' region. ${ }^{20}$ The ratification of human rights conventions played an important role in the region's international rehabilitation in the 1990s and acted as a support mechanism for democratization. ${ }^{21}$ Despite a 'Latin bias' in the Anglo-American media with regards to rights violations, ${ }^{22}$ Latin America has actually made a significant contribution to the creation of international human rights norms. ${ }^{23}$ Furthermore, over the last decade the region has gone through a process of political and social transformation, with the electoral victory of leftist governments in most of South American countries (what has been called the 'pink wave' or the 'left turn') and the introduction of a so-called 'postneoliberal' economic model. Postneoliberalism marked the 'return of the state' in Latin American economies, in particular through a wave of social protection policies targeted at vulnerable populations and a stronger regulatory agenda in a range of sectors, including labor, environment and health. ${ }^{24}$ Governments and social movements in the region have begun to speak of economic and social rights, as well as classic liberal rights ${ }^{25}$, and have shown a willingness to frame independent approaches to rights questions. ${ }^{26}$

Both Argentina and Bolivia joined the 'left turn' that swept the region in the earlymid 2000s, with the electoral victory of popular coalitions led respectively by the Peronista Nestor Kirchner and by the coca-growers union leader Evo Morales ${ }^{27}$. However, as with all 'interruptions' to neoliberalism ${ }^{28}$ in Latin America, new left governance is nationally distinctive. In Bolivia, given the organizational strength of the indigenous and peasant movements, policies have been shaped by discourses that reject both neoliberalism and colonialism and emphasize the possibilities of more pluralistic and autochthonous forms of governance (at the core of the new 2009 Constitution and the model of plurinational state) ${ }^{29}$. In Argentina, in contrast, post-neoliberalism was associated above all, with a resurgence of trade union claims, workers' rights, the creation of employment and a new 'decent work' agenda. ${ }^{30}$ The Argentine state, moreover, resumed its traditional dominance over civil society. ${ }^{31}$ The two countries are also significantly different in terms of their levels of economic development ${ }^{32}$, although both have undergone a process of in-depth social reforms and strengthened the role of the state in the economy. 
Methodologically, focusing on these two cases allows us to compare different postratification compliance politics in the framework of relatively similar macro-political and economic processes that are also part of a common regional trend. We have sought to eliminate the possibility that the complex domestic politics of compliance with regard to child labor could simply be attributed to hostility or opposition to international human rights agreements - though they may play a part - so we can zoom in on the detail of domestic differences in interpretation of the rights obligations of states in two cases where governments express commitments to human rights principles in general. To be clear, then, we are not comparing compliance disputes between countries where one or both are hostile to the idea of rights-based policy-making; rather we are consciously trying to uncover what lies beneath cases where the importance of rights is acknowledged but where there is nonetheless considerable divergence from international norms in terms of compliance outcomes.

Qualitative research is particularly good for examining socially constructed meanings in context. As such, the research relies on intensive fieldwork in both Bolivia and Argentina between July 2013 and September 2014. Fifty-four people (twenty-two in Bolivia and thirtytwo in Argentina) were interviewed, including representatives of national and international organizations (Ministries, Ombudsman officers, Members of Parliament MPs, public attorneys, representatives of ILO, UNICEF, United Nations Development Programme UNDP, Office of the United Nations High Commissioner for Human Rights OHCHR), civil society organizations (CSOs, including children movements and national and international NGOs), trade unions and the private sector. In Bolivia, the research took place during the heated national debate that would lead to Law 548 (also called Children's and Adolescents' Code) and we were able to complement one-to-one interviews with participant observations at workshops organized for and by working children's organizations, and meetings between civil society groups and state authorities to discuss the reform. In Argentina, the differences with Bolivia were discussed at a seminar that included policymakers and social actors as well as academics, organized at the University of Palermo. An analysis of a range of relevant documentation was also carried out for both cases, including government, international organizations and civil society reports, internal policy documents, campaign and outreach materials. These documents were useful to complement information obtained through interviews and particularly to gather information on official statements, internal discussions and discourse and communication strategies of different actors. In 2015, further interviews were conducted at the ILO and UNICEF headquarters in Geneva and New York with nine international officers working on child labor, some of whom spoke to us on condition of anonymity.

\section{On the Politics of Compliance}

For many years, research on international human rights agreements was inspired principally by international law or international relations. ${ }^{33}$ Such scholarship provided convincing explanations on why states chose to ratify human rights agreements, but not on what happened after ratification. The importance of post-ratification politics for explaining the meaning of ratification was first highlighted by scholars of civil society, social movements and advocacy politics, who emphasized the key role of globalization as a resource for 
domestic activists. ${ }^{34}$ This led to research that explored the ways in which domestic civil society actors engaged with global rights agreements inside the national state after ratification. ${ }^{35}$ But as Cardenas ${ }^{36}$ points out, outcomes from domestic debates about the meaning of post-ratification compliance are shaped not only by civil society but also by the state and the resources it can deploy. Beth Simmons ${ }^{37}$ also pays attention to the state, as well as civil society, in what is the most complete review of why domestic politics matters for human rights compliance. Simmons argues that pro-rights reform can occur if the executive strongly backs reforms inspired by international law or in cases where the courts or parliaments press for new legislation, as well as when there is domestic civil society mobilization.

There is agreement, then, that the domestic level matters. As Hillebrecht recently noted: "understanding compliance with human rights law requires delving into the relationship amongst domestic political actors and a parsing out of their motivations, capacities and institutional strengths" ${ }^{38}$. In their discussions of children's rights in Latin America, Grugel and Peruzzotti ${ }^{39}$ describe the coming together of groups of state and nonstate actors to press for the adoption of particular policies post-ratifications as 'compliance coalitions'. They emphasise the fluidity of such coalitions and the way their make-up shapes how the agenda of compliance is understood. But compliance coalitions also shape broader discussions of human rights. And whilst initially research emphasized the role of civil society above all in compliance, there is an increasing awareness of the role of governments in actively shaping post-ratification compliance debates.

Domestic responses to the ratification of international rights are shaped not only by the resources civil society and states bring to the debate but also by competing ideas, interests and interpretations about what being compliant means. As Grugel and Peruzzotti ${ }^{40}$ argue, the politics of compliance is not "simply about whether a particular set of human rights claims are seen domestically as legitimate (...). [It] can also involve a conflict of interpretation over what treaty obligations mean; how to translate rights principles into domestic law, policy and practice; and what issues should be prioritized for reform". There is not, in other words, one single route to compliance or one unique set of policy responses that should be understood as being rights-compliant; different outcomes after ratification might reflect different interpretations of what rights actually mean. This room for manoeuvre around what compliance means reflects the fact that international rights agreements set out shared principles but do not always provide a single roadmap on how to achieve them. Additionally the actions proposed by international rights agreements do not always resonate in domestic settings.

In practice, compliance politics entails something more than the inclusion of international treaties in domestic laws or the respect and monitoring of human rights. Compliance can acquire quite different meanings depending on how states and domestic actors interpret human rights and the moral principles that underpin them. We understand compliance as the process of reform of national legislation and policy frameworks to adhere to certain rights principles shaped by international human rights norms and reinterpreted through a domestic process of 'translation' and socio-political negotiation. As such, we take a somewhat less rigid than traditional definition of compliance (Chayes and Chayes 1993, Simmons 2009) and allows for broader variation in the interpretation of rights principles. In 
fact, although compliance has been generally understood as the alignment of domestic laws and policies with international agreements, in practice it is possible to be sympathetic to the general principles underlying a rights treaty and, at the same time, differ substantially on how the rights that underpin international law should be interpreted. When this happens, we argue that, the concept of compliance should not be dismissed a priori; there is first a need to explore whether the state in question is reinterpreting the norm in ways that 'make sense' locally and searching for ways to ensure that their citizens benefit from rights protection. We also recognize that compliance is, in practice, a process; however, we wish to zoom in here on the initial legal response, which is the first step to broader change. We draw from Simmons (2009) argument about the sincerity of ratification to note that states may seek 'sincerely' to comply, even when implementation practices are patchy and problematic. As such, from an operational perspective our definition limits the empirical focus on legal and policy instruments, leaving aside the evaluation of the effectiveness of legal measures and policy implementation.

\section{Bolivia: Deviant Compliance and the Limited Legalization of Child Work}

Child labour in Bolivia has recently been the object of considerable international attention following the approval, in July 2014, of a new Children's and Adolescents' Code (Law 548). The Code recognizes child labor as exceptional but nonetheless it allows children to work from ten years of age for self-employed children and twelve for children who work for others, if authorized by the Child Ombudsman Office. The Code was accompanied by promises from the government to increase monitoring so as to eliminate the exploitation of children in the workplace and forced child labor. Nevertheless, despite these steps to ensure that children's rights in the workplace would be upheld, several NGOs, including Human Rights Watch (HRW) and Anti-Slavery International (ASI), have condemned the new Code. ${ }^{41}$ The policy has also been denounced by the ILO's Committee of Experts on the Application of Conventions and Recommendations as a violation of the Minimum Age Convention (C.138), urging the government to amend the $1 \mathrm{law}^{42}$. Indeed it is hard to deny that the Code represents a deviation from strict compliance with ILO agreements. But the Bolivian response, we argue, is not the result of the country's unwillingness to comply with the Convention, but reflects rather an alternative interpretation of children's rights and best interests.

Child labor is a both a visible and significant phenomenon in Bolivia. According to the last National Labor Survey, more than 28 per cent of Bolivian children and young people between the ages of five and seventeen - almost 850,000 - take part in some kind of economic activities. ${ }^{43}$ In line with international statistics, levels of participation are much higher in rural areas ( 65 per cent) and the majority of children are employed in the agriculture sector (50,2 per cent) or sell on the streets (21 per cent). Only a few of them work as labourers (13,7 per cent) and even less (13 per cent) are qualified workers. The scale and pervasiveness of child labor have undoubtedly contributed to the domestic politicization of the issue. But, added to this, is the fact that the domestic debate about child labor has taken place against a backdrop of intense national debate about the nature of citizenship itself and Bolivia's place within the global political economy. This had shaped the interpretations of 
Bolivia's obligations with regard to ILO conventions, within both civil society and the state, in a very distinctive way.

Bolivia's first Children's and Adolescents' Code had been promulgated in 1999, in response to ratification of the UNCRC. Ratification of the minimum age Convention, C.138, has taken place just two years earlier, in 1997, but had no major impact on domestic policy. The Convention on the Worst Forms of Child Labor, C.182, was ratified in 2003, and was followed by the introduction of a national plan to eradicate child labor, supported by the ILO. But its impact was minimal. The debate about child labor that opened up around 2008 was sparked by a combination of heightened ILO pressures, especially in relation to exploitative or hazardous labor, and the Constitutional reform process in particular. The new Constitution approved in 2009 created a plurinational state that expressly set out to combine liberal democracy with collective rights and local, indigenous autonomies. ${ }^{44}$ Working children associations (Niños Niñas Adolecentes Trabajadores, NATs) had mobilized as part of the social movements' activities around the new Constitution and were already organized, therefore, in 2010 when the discussions opened to reform the 1999 Children's Code and review the National Plan to eradicate child labor.

The domestic debate, which did not close until Congress passed the new Law in 2014, was extraordinarily intense and conflictual. Tensions, which were sometimes framed around the place and interpretation of international rights law in national politics, took the form of a discussion as to how best to protect and promote children's rights. On the one side, were ranged civil society groups who tried to press the government to introduce eradicationist legislation, followed by new programmes of action to reduce child work and an enforcement of the minimum age. On the other side, were a second group of civil society movements, again supported by some government officials and, crucially, the Union of Bolivian Working Children and Adolescents (UNATSBO), who favoured the introduction of legislation that would uphold the rights of child workers and offer them protection through regularization of their status. Both camps claimed to have the wellbeing of child workers at heart.

The first group favoured strict adherence to ILO norms, arguing that "it makes no sense to create protective conditions when child labour is banned". ${ }^{45}$ This view was widely shared by key political actors in the governing party and in Congress:

\footnotetext{
It is pointless to legalize child labor, because the result would be to create a state policy based on the belief that the new generation of men and women are trained in schools, in the family and at work, and this is not the vision of a society that we want to build. Also it has been proved that children who work do not receive a proper education. ${ }^{46}$
}

The second group, meanwhile, pushed for an interpretation of children's rights that meant stretching those norms in ways that could fit a domestic political economy where young people's work was both valued and recognized as essential to family survival. This was important: there were strong feelings that any reform that would proclaim the eradication of child labor as its goal would underline not only children's rights but also the traditional family-based economy. As working children told us during a workshop in Cochabamba:

The ILO has policies on labor but they work more internationally. What we would like more is a national organization that reflects the politics of Bolivia because we have our own national 
reality. We don't live in the same world as other countries (...). [Therefore] We don't want labour eradication. We want it to be valued since at the end we are contributing to the country. ${ }^{47}$

An interesting feature of the debate in Bolivia was that it was not a simple conflict between the state and civil society. Wide differences opened up within civil society and indeed, within the government itself. The pro-ILO/eradicationist party was led by the Ministry of Labor, which was close to the ILO, plus a number of local and international NGOs; while the pro-legalization movement included the NATs, along with NGOs such as Save the Children, Defence of Children International and some branches of Terre des Hommes, and donors such as the Italian Development Cooperation Agency. This second group also enjoyed the sympathy of governmental representatives in Congress and civil servants in the Ministry of Education and the Ombudsman Office. ${ }^{48}$ It was the second, prolegalization coalition that triumphed in the end, due as much to its resources as to the fact that the arguments it was making resonated with the broader political process that Bolivia is undergoing. UNATSBO was well-connected to the Constitutional Assembly (2006-2009) and highly effective at mobilizing to get its voice heard.

Children representatives went to Sucre [where the Constitutional Assembly was meeting], marched and presented their proposal, which was initially included but then erased in the final text. So they mobilized again, this time in Oruro. They stayed until they [the Assembly delegates] listened to them and they managed to agree the article directly with the President of the Assembly. This is one of the important achievements of the working children themselves, as a result of this negotiation. ${ }^{49}$

Although the ILO-sponsored group was well-funded and counted on a slick communication strategy, it was unable to access either the presidency or the governing party to the same extent than the legalizationist group. The latter also benefitted from the very marginal engagement of Bolivian unions in this discussion, thus removing one of the traditionally vocal actors against child labor from the debate.

Throughout the six-year long debate, each side accused the other of putting ideology over the needs and rights of children. But, perhaps surprisingly, references to right-based arguments were deployed by the pro-legalization lobby more often and consistently than by eradicationist supporters, as a way of consciously countering the view that ILO conventions were inevitably the best way to protect Bolivian children. Work, they argued, should be recognized as a right for children and adolescents; the presence of children in the labour force should not always be seen as a serious social problem. Echoing a Declaration of the International Working Children Movement, which explicitly mentions work as an "important human right" and central for children's personal development, ${ }^{50}$ UNATSBO's proposal for the new Code states that:

Working children and adolescents are primarily human rights subjects (...) the State is obliged to protect those rights, including the right to work and to participate in public life with their own opinion and participation; in short, addressing the regulation of child labour within a framework of human rights protection could imply a much more comprehensive framework of obligations' compliance and exercise of rights. ${ }^{51}$ 
The pro-ILO lobby, meanwhile, seemed to avoid invoking international rights discourses directly, perhaps in order to avoid a backlash against what might be seen as international imposition. As a result, few direct references were made to children's human rights and there was a reliance instead on evidence and arguments about the side effects of child labor, for example on children health and education.

A peak in the pro-legalization mobilization was reached in December 2013 when a group of working children demonstrated in La Paz in favour of their rights to work and were dispersed by police violence. The Office of the Presidency openly criticised the repression and President Evo Morales met with NATs' leaders, and finally made public his own position on child labor. ${ }^{52}$ An ex-child worker himself, Morales grow up in a rural indigenous community of the Bolivian highlands. His sympathies were undoubtedly with working children. Moreover, Morales' leadership relies on his ability to articulate demands from traditionally excluded social sectors and his willingness to offer a radically different approach to Bolivian politics, historically dominated by economic elites and old oligarchies. In this context, the claims of the NATs about the inappropriateness of an eradicationist approach for Bolivian multicultural society and the reflection of a western ideal of childhood resonated with a broader critique of colonialism and domestic scepticism vis-a-vis liberal global governance. During a press conference in December 2013, President Morales went on record saying that: "child labor shouldn't be eradicated; yet children should not be exploited or forced to work. Some work out of necessity. To eliminate children and adolescents' work is to eliminate their social conscience". ${ }^{53}$ Morales' intervention may just have swung the debate. Six months later the new controversial Code was promulgated.

This story of how the new Children Code was approved sheds light on the dynamic that led to the new, and controversial, approach on child labor in Bolivia and the different domestic understandings of how the state should deliver on its obligations to vulnerable children. These differences, as we have illustrated, did not shape up along the lines of civil society versus the state, with civil society demanding the introduction of policies to protect children or keep them out of the labor force. Rather there were voices within both civil society and the state in favour of the introduction of measures that would seek to eradicate child labor (whatever the implementation difficulties); and equally voices within civil society and the state that demanded that the government recognises the difficulties of eradication and acknowledge the right of child workers to make a contribution to the family through work. Yet the outcome was not only shaped by these ideational disputes but by the institutional resources that each side brought to the dispute. ${ }^{54}$ In the end, capturing the ear of the Presidency and his closest allies in the ruling party, which had a majority in Congress, was crucial. In other words, the law was not the outcome of a process of negotiation and consensus-building, but the result of highly vocal social groups who reached a political settlement with the government.

The government is resolute in its conviction that the new Code, not only is not a violation of children's rights, but that it offers them protection. The Code has been presented as an improvement in rights terms, and the result of an inclusive process in which children were recognized as social actors in their own right. With the argument that the Code will ensure the "full and effective enjoyment of [children's] rights" and safeguard "the interests of 
[children], in accordance with the State Constitution and international treaties on human rights", in March 2015, the Bolivian government stood firm and rejected the recommendations made in the framework of the Universal Periodic Review. ${ }^{55}$ This position was again confirmed during a meeting of the European Parliament's Committee on Development to discuss the Code, where the Bolivian Ambassador stressed that:

\begin{abstract}
It is a law in which children are not objects for which standards are available and administrative procedures are established but (...) are the actors and subjects bearers of rights and duties. (...) With this law, the norm is adapted to fit the existing context (..), to a particular socio-cultural reality, while in international conventions views have been marked by a Western conception. ${ }^{56}$
\end{abstract}

\title{
Argentina: Over-compliance and Criminalization
}

In contrast to Bolivia, in Argentina the internal debates about state obligations with regard to child labor were considerably less acrimonious. The outcome was also remarkably different, with the government introducing measures that far exceeded ILO recommendations with respect to both the minimum age for work (C.138) and to C.182 or the elimination of all forms of hazardous labor. In 2008, the minimum working age was increased from fourteen to sixteen and a government unit to protect working adolescents was created (Law 26.390). Even more remarkably, Argentina criminalized the employment of children in 2013 (Article 148bis of the Penal Code), making it punishable with up to four years in prison, the only exceptions being parents and guardians. A public attorney specialized in children rights called this "a symbolic act in itself, sending the message that this society thinks it is bad that children work". ${ }^{57}$ As well as being symbolic, however, the law is intended to have teeth: between March 2013, when the reform was approved, and August 2014, the Ministry of Labor has brought 105 cases against employers of children (63.3 per cent in the trade and service sector and 20 per cent in rural labour), although none has yet reached a definite judgement.

As with Bolivia, Argentina was governed, until December 2015 and during the period of reform of child labor statutes, by a nationalist party that frequently expressed independent views from the US and the Western mainstream. What accounts, then, for the introduction of policies that accept the rightness of the ILO's opposition to child labor, but go much further than ILO, and which are, at the same time, markedly different from those adopted by the left government in Bolivia? We suggest that Argentina's distinctive approach reflects the strength and cohesion of the domestic socio-political coalition against child labor, which brings together trade unions, public opinion and key state institutions such as the Ministry of Labor. The ILO kick-started a domestic debate in Argentina, as in Bolivia, but national policies are inspired not by ILO visions or the result of its influence over the Kirchner governments but by national actors and public opinion that take an even harder line than the ILO itself. The Director of the Committee for the Monitoring and Implementation of the International Convention on the Rights of the Child (CASACIDIN) put it this way:

Child labor is one of the few issues on which Argentinians fully agree. We cannot conceive ideologically of the idea that children can join trade unions and explaining that is a task in which unions have done very well. (...) In addition, in this country, there was no tradition of 
children to work from a young age (...). The school culture was always very strong. There is no organization that promotes child labor. ${ }^{58}$

This view was echoed across all interviews we held with trade union leaders and civil servants. ${ }^{59}$

This consensus and Argentina's response to child labor is rooted in the traumatic 2001 economic crisis and the politicization of child labor that took place at that time. The rapid pauperization that followed the economic meltdown pushed thousands of children into the street in search for work in the informal sector. In 2003, the Office for the Children's Rights of Buenos Aires estimated that there were between 3,500 and 4,000 children working as cartoneros, gathering recyclable waste on the street to be sold to recycling enterprises and intermediaries. ${ }^{60}$ Initially, then, child labor came onto the policy agenda framed as an aberration; it was regarded as a sudden reaction to economic crisis and extreme austerity, a measure of how far the country had fallen. But as growth returned, it was clear that the cartoneros were only the most visible face of child labor. Research established that around 14 per cent of Argentine children between five and seventeen work, most of whom also attend school. ${ }^{61}$ Many of these children are immigrants, especially from Bolivia and Paraguay, and they are employed in the service sector ( 78 per cent), agriculture (13 per cent) and industry ( 7 per cent).

The shock of the economic crisis and the sudden visibility of children working even in the most upmarket areas of the capital marked a turning point in national attitudes. Up until that time, little public attention had been paid to the issue. Furthermore, during the 1990s civil society views were divided between children's rights advocacy groups who simply accepted ILO approaches, and a smaller number of vocal organizations who worked directly with marginalized children, such as the Chicos del Pueblo movement. These groups tended to articulate positions not dissimilar from social movements in Bolivia and they sought to find value in children's work, recognising the contribution the children were making to family survival strategies. ${ }^{62}$ After the ratification of C.182, in 2001, however, and in the midst of a much more serious public and political engagement with children's rights in general, ${ }^{63}$ the pro-legalization movements, which were previously respected amongst children's rights groups, found themselves marginalized. The pro-eradication lobby mainly formed by unions, meanwhile, has allied with the government, which suddenly took the issue up as part of its post-crisis strategy, and implemented policies that go significantly beyond ILO proposals.

The legitimacy of both the government of Nestor Kirchner and of Cristina Fernández de Kirchner, in office between 2003 and 2015, rested on the image they presented as governments committed to the interests of the poorest in society. The eradication of child labor became part of a wider approach that includes the extension of child welfare benefits and workers' rights. ${ }^{64}$ Moreover, for governments that were criticized at times for their human rights practices, ${ }^{65}$ this was an area where the high moral ground can be claimed. As a result of presidential backing, the Ministry of Labor, itself traditionally a powerful department under Peronism and one that, moreover, had benefited from staff continuity because of the ten-year long Kirchner-Fernández Kirchner governments, created a National Commission for the Eradication of Child Labor (CONAETI) and drafted a series of fiveyears National Plans (2006-2010 and 2011-2015). Other initiatives included the 
establishment of a coordination office for child labour inspection and the introduction of the first survey on child labor. Government action reflects the public mood that child labor is an aberration in Argentina, associated above all with the 2001 crisis, and one that could be eradicated if swift action is taken. It is grounded in the belief that child labour and children rights are fundamentally incompatible:

\footnotetext{
Argentina addresses the issue of child labor from a rights perspective. This is the key point: to understand that children have the right not to work until the age at which they are prepared mentally and physically to do so. Child labor (...) violates the UNCRC. ${ }^{66}$
}

In this case, therefore, the agency of the state has been crucial; outcomes have not been driven by civil society. Indeed, the NGOs sector has played a relatively marginal role in the fight against child labour. Only a few national organizations have really been involved, while international NGOs, especially those that take a pragmatic view, have not been able to influence the public debate - indeed Save the Children was completely marginalized and eventually closed its country office in 2013. Instead, the government's response depended on support from its long-term ally - the trade union movement. The powerful General Workers Union (CGT) had, in fact, come out in favour of eradication of child labor in the mid-1990s, before the issue was really in the public consciousness. It had also taken a lead on the issue within MERCOSUR. The CGT saw itself "as a watchdog" on labor rights, and views child labor as an abuse of those rights. ${ }^{67}$ In those sectors where child labor is regarded as significant, unions have put in place strategies to combat it. The teachers' union (CTERA) has also been active in organizing awareness campaigns. The cartoneros union recently signed an agreement with the Buenos Aires city government to create nurseries for its affiliates, while the ladrilleros (brick-makers) union - where a high percentage of workers come from Bolivia and child labour is particularly widespread - is directly involved in the programme of inspections coordinated by the Ministry of Labor. ${ }^{68}$ Interestingly, business groups also joined the fight against child labor. In 2004, fifty-five national companies signed a Declaration against Child Labour calling for the prohibition of the employment of children below the minimum age, ${ }^{69}$ and, in 2007, the CONAETI led the formation of a Network of Enterprises Against Child Labour. This led to the creation of a joint public-private programme called Harvest Gardens (Jardines de Cosecha) to create nurseries and play centres for children.

In sum, a strong, relatively efficient and determined state took the lead in articulating a national response that goes beyond ILO recommendations. In fact, neither the ILO nor national and international NGOs have played much of a role in developing national policy. Instead, the government has relied mainly on the union movement. But civil society is certainly not hostile to government actions. The pro-legalization lobby was never dominant, even in the 1990s, and the shock of the 2001 economic crisis led to the consolidation of a view in favour of the elimination of child labor. Once it was marginalized, the government was able to introduce a raft of policies that rested on a widespread view in the country that child labor was not to be tolerated and that firm action to eradicate it and the introduction of new welfare policies would be able to eradicate it. As such, the country has set out a sui generis approach that engages only tangentially with ILO recommendations - Argentina has 
not yet set out a list of what constitutes hazardous work for children, for example, which is formally required by C.182 - that reflects national views that child labor is both abhorrent and alien to national culture.

\section{Comparing Divergent Compliance and Restating the Importance of Domestic Politics}

In both Argentina and Bolivia, children's rights and the debate about how best to protect the rights of working children have, quite clearly, been taken very seriously; equally, governments and civil societies in both countries evidently regard the international conventions that govern child labor as important starting point for domestic debate. Yet in neither country have governments simply aligned domestic law with the international rights agreement. Instead, they have sought, in radically different ways, to adjust international child labor norms and shape them in ways that reflect domestic perceptions of children's rights in relation to work. These are, then, somewhat different models of compliance.

In Bolivia, civil society actors were dominant in domestic debates and discussions have been deeply acrimonious. Civil society has divided between those that support eradicationist approaches and those in favour of legalization. ILO activism, combined with the opening up of a national debate about the Constitution and how best to balance indigenous practices and democratic principles created a new 'opportunity structure' for action, but not one that led to a pragmatic coming-together of civil society organizations as described in some literatures on social movements. ${ }^{70}$ Instead, both sides were able to count on allies internationally and nationally. ${ }^{71}$ This led to the coexistence of two competing coalitions, neither of which gave way. While both these coalitions were able to marshal human rights arguments to support their views, they offered quite different interpretations of what children's rights mean in relation to work. The pro-eradication coalition pushed for reform that mirrored the text of ILO conventions (C.138 and C.182) or responsive compliance. The pro-legalization group, meanwhile, developed an alternative discourse and roadmap in which the right to work should be recognized to children as a way of ensuring measures of protection and avoid exploitation (and violations of other human rights). They argued for a form of deviant compliance - a law that was in violation of C.138 on the minimum age but which also set out standards and protection for children in the workplace. This group managed to win the argument once they caught the ear of a government that has consistently been willing to promote the idea of Bolivia as independent from Western influence.

In Argentina, the collapse of the economy in 2001 created a receptive context for the government to take the lead on child labor, in the framework of a wider welfare reform. In this fight, the Ministry of Labor found a key ally in the trade unions sector. The unions had traditionally opposed child labor and, additionally they had increased their influence after the crisis $^{72}$. Not only has Argentina taken seriously ILO compliance targets, it has also set out its own ambitious proposals to crack down on child labor. Quite clearly, the government has not been a passive recipient of international norms. Indeed, the repeated postponement of the list of hazardous employment for children, which is a requirement under C.182, suggests in this case not a government tolerant of less dangerous forms of child labor, but one that is 
determined to eradicate all forms, and for whom the list is therefore seen as irrelevant. Furthermore, the recent law that criminalizes child labor exploitation does not distinguish between acceptable and unacceptable forms of work. Argentina is therefore a case of a overcompliance and a government determined not simply to follow the ILO conventions but to set more ambitious standards for eradication.

Understanding why and how countries comply with international human rights norms is a complex endeavour. ${ }^{73}$ Domestic politics is as central to the 'how' as to the 'why'. In fact, the really interesting feature of Bolivia and Argentina's compliance with international child labor agreements is not so much 'why' - we would expect generally rights-respecting democratic countries to do so - but 'how'. Their divergent patterns of compliance, which can only be explained through the lens of domestic politics, draw clearly on two factors: the socio-political settlement combined with the institutional resources of civil society and state actors; and domestic perspectives on the fitness of the international agreement. But these domestic debates are also playing out in a broader geopolitical context that will almost certainly have an impact on the global reception of human rights ideas.

In Argentina and Bolivia, institutional resources and patterns of civil society/state interaction have been crucial for shaping outcomes in relation to child labor. Both countries have highly mobilized civil societies and active trade union movements. However, while in the case of Argentina major trade unions took a leadership role in consolidating an anti-child labour coalition (mirroring what have generally happened in Western countries and at the international level), in Bolivia, the unions stayed at the margins and debates were led by the NATs movements demanding the right to work, with the support of international NGOs and donors. State attitudes are also fundamental for explaining outcomes: Argentina is an example of how a strong leadership by state institutions, supported by the continuity of key administration's managers in their positions and a relatively efficient bureaucracy, led to the definition of a coherent strategy, at least at the national level. This was not the case in Bolivia, where different state institutions and ministries have adopted conflicting and changing stands on child labour. This can be attributed in part to the lack of leadership within the state apparatus as well as to the fragmented and volatile nature of Bolivian public administration. It was the fact that Bolivian actors, and perhaps especially Bolivian children, were driving the debate that meant that the state finally took a view in support of what has come to be seen internally as the most appropriate strategy, but also as one that asserts the right of Bolivia to 'be different' from the international norm. Outcomes are in part the result, then, of the extent to which the resources of, and relationships between, governing elites and the coalition of actors leading the discussion within civil society articulate.

Beyond the underlying relationships and resources of state and civil society, and the contingent political processes associated with them, domestic views on the fitness of international child labor norms were also important. The difficulties of embedding international human rights norms, which after all tend to codify a particular morality associated with the West and the European Enlightenment, in contexts that do not share the same cultural background are well known. ${ }^{74}$ These difficulties can be accentuated when the international norms set out to prescribe daily family life and familial political economies. In this sense, the debate on child labour is an exceptionally moral dispute, with only a limited degree of pragmatism. It tends to ignores the difficulty of defining what constitutes child 
labor in much of the global South and ignore the fact that many "activities (...) fall between exploitation and abuse on the one hand and helping-out on the other", ${ }^{75}$ such as part-time self-employment or family agriculture. ${ }^{76}$ Child labor norms are, in fact, quite different from the approach taken with regard to the UNCRC, which allows considerable room for national negotiation and where, in any case, monitoring is both weak and generally supportive of governments. In this case, Bolivian social movements, and ultimately the government, concurred with the view that international norms on child labor were inappropriate and would not improve the rights of children. Instead, they opted for a deviant form of compliance that has sought to put in place novel ways to protect child workers. Argentina, in contrast, seized the opportunity to present itself as a leader on human rights internationally by going far beyond the ILO recommendations. Only time will tell whether either deviant or overcompliance will lead to greater rights for children than the middle way proposed by the ILO.

Finally, distinctive Bolivian and Argentinian responses have emerged in a changing geopolitical context. It is certainly the case that the Latin America region is rights-respecting and has been an enthusiastic backer of the creation of international human rights standards. Nevertheless, there is a growing sense in both countries that it is time for rights standards to be set at the national level. This may well reflect growing resistance of new emerging powers and middle-income countries to Western impositions. In the 1990s, soon after the collapse of the Soviet block, many governments worldwide tried to model themselves on Western norms, in the effort to reproduce similar levels of prosperity and stability and to gain the benevolence, political and economic support of Europe and the United States. ${ }^{77}$ As part of this process, countries were willing to ratify international treaties and add human rights to their constitutions as a sign of their willingness to adapt to that model. Since then, fresh challenges to Western dominance have emerged, not just from areas previously thought of as the 'global South', but also because it has become clear that the Western model of progress has significant limitations and does not guarantee either economic development or social progress. Dissent from ILO prescriptions in both Argentina and Bolivia may well reflect a global context in which divergence from the Western norm is becoming more common.

\section{Conclusions}

Over the last decade, constructivist research in anthropology and international relations has shown that the way international human rights norms are 'translated' or adapted to local circumstances plays a major role in shaping compliance. ${ }^{78}$ Grugel and Peruzzotti ${ }^{79}$ reveal how state and non-state actors have engaged in acts of 'translation' in relation to children's rights in Latin America, resulting in quite different national priorities for reform. But their evidence ${ }^{80}$ comes from governments that were keen to be associated with implementation of human rights agreements as a way of shoring up new or recent democracies - in relation to a human rights convention, the UNCRC, that allows governments to focus on some issues and shelve others. This meant that the advocates of rights-based reforms were generally responsive to international agendas for human rights implementation. They were able to circumvent claims that the UNCRC codified 'inappropriate' norms or was externally imposed in ways that are simply not possible in relation to the far more precise ILO-sponsored norms on child labour. Indeed, in relation to child labor, there is agreement that children should not 
carry out age-inappropriate work or work that is harmful for them, but no agreement as to what work is harmful or what age is inappropriate for a particular task. So, whilst on the surface, human rights law on child labor (and particularly C.182 and C.138) seems reasonably straightforward and clear, in fact, it leaves considerable room for domestic variation.

Child labor is therefore a good example of those norms where domestic translation has been particularly contested. These tensions have been explored so far through the lens of anthropology and economics. But they have significance for human rights scholarship as well. This paper shown how, even in contexts characterized by similar macro-political processes and with a shared concern for children's rights, models of compliance can lead to very different policy outcomes that diverge significantly from international conventions and guidelines. In this sense both Bolivia and Argentina are stories of extremes. Both countries take the norm seriously as well as their commitment to a rights-based agenda. And both countries move beyond a responsive model of compliance. Bolivia and Argentina are not ignoring human rights law, nor are they trying to avoid the costs of 'translation'. For Bolivia, there are political costs to pay in taking a deviant compliance approach because of the international condemnation that has followed. Argentina, meanwhile, has embarked on a costly eradication strategy, which requires investments in both the judiciary and the regulatory system. Ultimately, the evidence here speaks to the need for a more nuanced understanding of what compliance means and the recognition of domestic inputs in its formulation.

\section{Acknowledgements}

We would like to gratefully acknowledge the cooperation of the people in Bolivia and Argentina that participated in this research and where willing to share time and information with us. The project was supported by the European Union's Horizon 2020 research and innovation programme under the Marie Sklodowska-Curie grant agreement No 655710. Field research in Bolivia was funded by the Sheffield Institute for International Development (SIID) while fieldwork in Argentina was funded through a Santander Research Mobility Award. We would like to thank the Universidad de Palermo in Buenos Aires for hosting us during our time there.

\section{Endnotes}

\footnotetext{
${ }^{1}$ Beth A. Simmons, Mobilizing for human rights: international law in domestic politics. Cambridge: Cambridge University Press (2009); Oona A. Hathaway, "Do human rights treaties make a difference?." Yale Law Journal 111, no. 8: 1935-2042 (2002); Jack. Donnelly, Universal human rights in theory and practice. Ithaca, NY:

Cornell University Press (2013).
} 
${ }^{2}$ Thomas Pegram, Diffusion across political systems: the global spread of national human rights institutions. Human Rights Quarterly 32, no. 3: 729-760 (2010).

${ }^{3}$ Simmons 2009, cit.

${ }^{4}$ Emilie M. Hafner- Burton and Kiyoteru Tsutsui, "Human Rights in a Globalizing World: The Paradox of Empty Promises." American journal of sociology 110, no. 5: 1373-1411 (2005); Sonia Cardenas, Conflict and compliance: State responses to international human rights pressure. Philadelphia, PA: University of Pennsylvania Press (2007), Jean Grugel and Enrique Peruzzotti, "The Domestic Politics of International Human Rights Law: Implementing the Convention on the Rights of the Child in Ecuador, Chile, and Argentina." Human Rights Quarterly 34.1: 178-198 (2012).

${ }_{5}^{5}$ Abram Chayes and Antonia Handler Chayes. "On compliance." International organization 47, no. 2: 175-205, 176 (1993).

${ }^{6}$ David P Forsythe, Human rights in international relations. Cambridge: Cambridge University Press (2012); Simmons (2009), cit.; Thomas Risse and Kathryn Sikkink "The socialization of international human rights norms into domestic practices: introduction." Cambridge Studies In International Relations 66: 1-38 (1999). ${ }^{7}$ Thomas Risse "International norms and domestic change: Arguing and communicative behavior in the human rights area." Politics \& Society 27.4: 529-559 (1999); Sally Engle Merry, Human Rights and Gender Violence: Translating International Law into Local Justice. Chicago: University of Chicago Press (2006); Ilias Bantekas and Lutz Oette. International human rights law and practice. Cambridge: Cambridge University Press (2013). ${ }^{8}$ The idea of norms 'over-compliance' has been widely used in environmental economics to study firms' compliance with environmental regulations (Jay P. Shimshack and Michael B. Ward. "Enforcement and overcompliance". Journal of Environmental Economics and Management, 55, no. 1: $90-10$ (2008); Seema Arora and Shubhashis Gangopadhyay. "Toward a theoretical model of voluntary overcompliance." Journal of economic behavior \& organization 28, no. 3: 289-309 (1995)). Over-compliance with respect to human rights norms has not been fully explored yet and there is no developed theory to explain why a state would over-comply with international commitments (Sheryl R. Lightfoot. "Indigenous rights in international politics: The case of “overcompliant” liberal states." Alternatives: Global, Local, Political 33, no.1: 83-104 (2008)).

${ }^{9}$ Simmons (2009), cit.; Grugel and Peruzzotti (2012), cit..

${ }^{10}$ Kaushik. Basu. "Child labor: cause, consequence, and cure, with remarks on international labor standards." Journal of Economic Literature 37, no. 3: 1083-1119 (1999); Kaushik Basu and Zafiris Tzannatos. "The Global Child Labor Problem: What do we know and what can we do?." The world bank economic review 17, no. 2: 
147-173 (2003); Patrick M. Emerson and André Portela Souza. Is child labor harmful? The impact of working earlier in life on adult earnings. Working Paper 3027, IZA Discussion Papers (2007); Alessandro Cigno and Furio C. Rosati. The economics of child labour. Oxford: Oxford University Press (2005); Matthias Doepke and Fabrizio Zilibotti. "The macroeconomics of child labor regulation." American Economic Review 95, no. 5: 14921524 (2005); Nicola Phillips. "Informality, global production networks and the dynamics of 'adverse incorporation'." Global Networks 11, no. 3: 380-397 (2011); Daniel Berliner, Margaret Levi, Anne Greenleaf, Milli Lake and Jennifer Noveck. Labor Standards in International Supply Chains: Aligning Rights and Incentives. Edward Elgar Publishing (2015).

${ }^{11}$ Olga Nieuwenhuys. "The Paradox of Child Labor and Anthropology". Annual Review of Anthropology 25, 237-251 (1996); Samantha Punch. "Household division of labour: generation, gender, age, birth order and sibling composition." Work, employment \& society 15, no. 4: 803-823 (2001); Sarah C. White. "From the politics of poverty to the politics of identity? Child rights and working children in Bangladesh." Journal of International Development 14, no. 6: 725-735 (2002).

${ }^{12}$ See Myers, William E. "The right rights? Child labor in a globalizing world." The Annals of the American Academy of Political and Social Science 575, no. 1: 38-55 (2001); Zehra F. Arat. “Analyzing child labor as a human rights issue: Its causes, aggravating policies, and alternative proposals". Human Rights Quarterly 24, no.1: 177-204 (2002); Simmons (2009), cit..

${ }^{13}$ Interview with UNICEF Senior Advisor on Child Labor, New York, June 2015.

${ }^{14}$ ILO. "The end of child labour: within reach" (2006). At:

http://www.ilo.org/public/english/standards/relm/ilc/ilc95/pdf/rep-i-b.pdf. Accessed 15 January 2015.

${ }^{15}$ ILO. "Accelerating Action against Child Labor" (2010). At:

http://www.ilo.org/wcmsp5/groups/public/@dgreports/@dcomm/documents/publication/wcms_126752.pdf. Accessed 15 January 2015.

${ }^{16}$ Jack Martin and David Tajgman. Eliminating the Worst Forms of Child Labour: a practical guide to ILO convention No. 182 Geneva: ILO (2002). At: http://www.ipu.org/PDF/publications/childlabour_en.pdf. Accessed 21 July 2015, 11.

${ }^{17}$ Michael Bourdillon. "Children and Work: A Review of Current Literature and Debates," Development and Change 37, no. 6: 1201-1226 (2006); Manfred Liebel et al. Children's rights from below: Cross-cultural perspectives. New York: Palgrave Macmillan (2012). 
${ }^{18}$ Cindi Katz. Growing up global: Economic restructuring and children's everyday lives. Minneapolis, MN: University of Minnesota Press (2004).

${ }^{19}$ ILO. "Declaration on Fundamental Principles and Rights at Work" (1998). At: http://www.ilo.org/declaration/lang--en/index.htm. Accessed 25 March 2015.

${ }^{20}$ Courtney Hillebrecht. "The Domestic Mechanisms of Compliance with International Law: Case Studies from the Inter-American Human Rights System”. Human Rights Quarterly 34, no. 2: 959- 985 (2012); David L., Richards and Ronald D. Gelleny. "Globalization and Government Respect for Human Rights in Developing Countries." In Chan, Steve, and James R. Scarritt. Coping with globalization: cross-national patterns in domestic governance and policy performance. Oxon: Routledge (2005).

${ }^{21}$ Francisco Panizza. "Human rights in the processes of transition and consolidation of democracy in Latin America." Political studies 43, no. 1: 168-188 (1995).

${ }^{22}$ Emilie Hafner- Burton and James Ron. "The Latin Bias: Regions, the Anglo- American Media, and Human Rights1." International Studies Quarterly 57, no. 3: 474-491 (2013).

${ }^{23}$ Kathryn Sikkink. "From pariah state to global protagonist: Argentina and the struggle for international human rights." Latin American Politics and Society 50, no.:1-29 (2008).

${ }^{24}$ Andrew Schrank. "Rewarding Regulation in Latin America." Politics \& Society 41.4: 487-495 (2013); Matthew Carnes and Isabela Mares. "Explaining the "Return of the State" in Middle-Income Countries Employment Vulnerability, Income, and Preferences for Social Protection in Latin America." Politics \& Society 43.4: 525-550 (2015); Steven Levitsky and Kenneth M. Roberts (eds.) The resurgence of the Latin American left. Baltimore: The Johns Hopkins University Press (2013); Laura Macdonald and Arne Ruckert, (eds.) Postneoliberalism in the Americas. New York: Palgrave Macmillan (2009).

${ }^{25}$ Paige Arthur. "How ‘Transitions' Reshaped Human Rights: A Conceptual History of Transitional Justice.” Human Rights Quarterly 31, no. 2: 321-67 (2009); Detlef Nolte et al. New Constitutionalism in Latin America. Promises and Practices. Farnham: Ashgate (2012).

${ }^{26}$ Lorenza B. Fontana and Jean Grugel. "To Eradicate or to Legalize? Child Labor Debates and ILO Convention 182 in Bolivia." Global Governance 21, no. 1: 61-78 (2015).

${ }^{27}$ Cristina Kirchner narrowly lost the presidential election in December 2015, putting an end to 13 years of Peronist government.

${ }^{28}$ Mark Goodale and Nancy G. Postero. Neoliberalism, interrupted: social change and contested governance in contemporary Latin America. Stanford: Stanford University Press (2013). 
${ }^{29}$ Nancy G. Postero. Now we are citizens: Indigenous politics in postmulticultural Bolivia. Stanford: Stanford University Press (2007).

${ }^{30}$ Pia Riggirozzi. “After Neoliberalism in Argentina: Reasserting Nationalism in an Open Economy”, in Jean Grugel and Pia Riggirozzi (eds) Governance After Neoliberalism in Latin America, pp. 98-112. Basingstoke: PalgraveMacmillan (2009); Candelaria Garay. "Social policy and collective action: Unemployed workers, community associations, and protest in Argentina." Politics \& Society 35, no. 2: 301-328 (2007).

${ }^{31}$ Carlos Gervasoni and Enrique Peruzzotti (eds.) Decada Ganada? Evaluando el legado del kirchnerismo Debate: Buenos Aires (2015).

${ }^{32}$ Argentina has a PIB per capita of $\$ 12.509,5$ compared to the $\$ 3.124,1$ of Bolivia (World Bank 2015). The two countries have experienced similar growth rates over the past 5 years between 16.44 in Argentina and 15.49 in Bolivia (IMF World Economic Outlook Database).

${ }^{33}$ Chayes and Chayes (1993); Ryan Goodman and Derek Jinks. Socializing states: Promoting human rights through international law. Oxford: Oxford University Press (2013).

${ }^{34}$ Keck and Sikkink (1998), cit..

${ }^{35}$ Teri L. Caraway. "Political openness and transnational activism: Comparative insights from Labor activism."

Politics \& Society 34.2: 277-304 (2006); Engle Merry (2006), cit.; Grugel and Peruzzotti (2012), cit.

${ }^{36}$ Cardenas (2007), cit.

${ }^{37}$ Simmons (2009), cit.

${ }^{38}$ Hillebrecht (2012), cit., 984-985.

${ }^{39}$ Grugel and Peruzzotti (2012), cit..

${ }^{40}$ Grugel and Peruzzotti (2012), cit..

${ }^{41} \mathrm{HRW}$ and ASI. Letter to the President Evo Morales (24.01.2014) signed by Global March Against Child Labor (2014). At:

http://www.hrw.org/sites/default/files/related_material/Letter\%20to\%20Bolivian\%20President(ENG).pdf

${ }^{42}$ ILO "Report of the Committee of Experts on the Application of Conventions and Recommendations" (2015).

At: http://www.ilo.org/wcmsp5/groups/public/---ed_norm/---

relconf/documents/meetingdocument/wcms 343022.pdf. Accessed 25 March 2015.

${ }^{43}$ INE/ILO. Magnitud y Características del Trabajo Infantil en Bolivia. La Paz: INE/ILO (2008). 
${ }^{44}$ Nancy G. Postero. "The Struggle to Create a Radical Democracy in Bolivia". Latin American Research

Review 45, no. 4: 59-78 (2010).

${ }^{45}$ Interview with UNICEF Protection Unit officer, La Paz, August 2013.

${ }^{46}$ Interview with Bolivian MP and president of the Parliamentary Network for Childhood and Adolescence, La Paz, August 2013.

${ }^{47}$ Interviews with NATs representatives, Cochabamba, August 2013.

${ }^{48}$ Interviews with Bolivian MPs; representative of Gruppo Volontario Civile (GVC); officer of the Ombudsman Office; Director of the Unit of Fundamental Rights at the Ministry of Labor; Save the Children, Terre des Hommes, Defence of Children International representatives; Director of the Fundación La Paz; and NATs representatives. La Paz and Cochabamba, July-August 2013.

${ }^{49}$ Interview with representative of Terre des Hommes Switzerland, Cochabamba, August 2013.

${ }^{50}$ Berlin Declaration (2004). At: www.enfants-actifs.org/?p=868 Accessed 10 July 2015.

${ }^{51}$ UNATSBO. Mi Fortaleza es mi Trabajo. La Paz: Terre des Hommes Suisse/Save the Children/Canada International Development Agency: 50 (2010).

${ }^{52}$ Veronica Smink. ¿Ilegal o parte de la cultura? El trabajo infantil divide a Bolivia. BBC Mundo Cono Sur. (14 Jan 2014). At: http://www.bbc.com/mundo/noticias/2014/01/140110_bolivia_trabajo_infantil_vs. Accessed 17 Jan. 2015.

${ }^{53}$ Página Siete. "Evo Morales contrario a prohibir trabajo infantile", (23 Dec 2013). At: www.paginasiete.bo/sociedad/2013/12/23/morales-contrario-prohibir-trabajo-infantil-9390.html. Accessed 25 June 2015.

${ }^{54}$ Cardenas (2007), cit.

${ }^{55}$ Edgar García. "Bolivia rechaza 15 recomendaciones sobre el trabajo infantil e independencia judicial", RIDH, (19 March 2015). At http://panorama.ridh.org/bolivia-rechaza-15-recomendaciones-sobre-el-trabajo-infantil-eindependencia-judicial/ Accessed 30 April 2015

${ }^{56}$ Video of the European Parliament's Committee on Development Session, 22.01.2015, 09:00/12:30. http://www.europarl.europa.eu/news/en/news-room/content/20150116IPR09877/html/Committee-on-

Development-meeting-22-01-2015-09001230

${ }^{57}$ Interview with Public Attorney, Buenos Aires, August 2014.

${ }^{58}$ Interview with the Director of CASACIDIN, Buenos Aires, August 2014. 
${ }^{59}$ Interviews with leaders and advisors of General Workers Union (CGT), Union of Education Workers of the Argentinian Republic (CTERA), Union of Brick-makers Workers of the Argentinian Republic (UORLA), Cartonero Workers Union (UTRACA), Buenos Aires and Buenos Aires Province, August-September 2014; Interview with Director of CONAETI, Buenos Aires, August 2014; Interviews with Director of the Ministry of Labor's Unit of Child Labor Inspections, Buenos Aires, September 2014.

${ }^{60}$ Interview with former Director of the Office for Children's Rights of the city of Buenos Aires, Buenos Aires, September 2014.

${ }^{61}$ Pontificia Universidad Católica Argentina. 2 de junio, dia mundial contra el trabajo infantil. Barómetro de la Deuda Social de la Infancia (2014). At: www.uca.edu.ar/uca/common/grupo81/files/12_de_junio_D-

a_Mundial_contra_el_Trabajo_Infantil_-_Final.pdf Accessed September 2014.

${ }^{62}$ Interviews with Chicos del Pueblo's Director and Founder and with Director of CASACIDIN, Buenos Aires, August 2014.

${ }^{63}$ Jean Grugel and Enrique Peruzzotti. "Grounding global norms in domestic politics: advocacy coalitions and the Convention on the Rights of the Child in Argentina." Journal of Latin American Studies 42, no. 1: 29-57 (2010).

${ }^{64}$ PNUD/CEPAL/OIT. RSE y Trabajo Decente en la Argentina. Contexto, desafios y oportunidades. Buenos Aires : Ministerio de Trabajo, Empleo y Seguridad Social (2009); Fabián Repetto and Virginia Tedeschi. Protección social para la infancia y la adolescencia en la Argentina Retos críticos para un sistema integral. Santiago de Chile: CEPAL/UNICEF (2013).

${ }^{65}$ Plataforma 2012. "La década kirchnerista y las violaciones de derechos humanos". Perfil, (7 December 2013). At: http://www.perfil.com/elobservador/La-decada-kirchnerista-y-las-violaciones-de-derechos-humanos20131207-0018.html Accessed 22 July 2015.

${ }^{66}$ Interview with the Director of CONAETI, Buenos Aires, August 2014.

${ }^{67}$ Interview with CGT Secretary for Child Labor and General Secretary of the Commission for the Eradication of Child Labor of the Coordinadora of the Unions of the Southern Cone, Buenos Aires, August 2014.

${ }^{68}$ Interviews with leaders of cartoneros and UORLA and CTERA, Buenos Aires, August-September 2014.

${ }^{69}$ ILO. "El trabajo infantil en la Argentina. Análisis y desafíos para la política pública” (2007). At: http://www.trabajo.gob.ar/downloads/biblioteca_libros/trabajo_infantil_argentina.pdf. Accessed 6 August 2014. 
${ }^{70}$ Margaret E. Keck and Kathryn Sikkink. "Transnational advocacy networks in international and regional politics." International Social Science Journal 51, no. 159: 89-101 (1999); Sidney Tarrow. The new transnational activism. Cambridge: Cambridge University Press (2005).

${ }^{71}$ Fontana and Grugel (2015), cit.

${ }^{72}$ World Politics Review, “Argentina’s General Strike Reflects Labor's Changing Political Role”. World Politics Review, (1 May 2014). At: http://www.worldpoliticsreview.com/trend-lines/13747/argentina-s-generalstrike-reflects-labor-s-changing-political-role

${ }^{73}$ Simmons (2009), cit..

${ }^{74}$ Diana Ayton-Shenker. The challenge of human rights and cultural diversity. Geneva: United Nations Department of Public Information (1995); Jack Donnelly. "The relative universality of human rights." Human Rights Quarterly 29, no.2: 281-306 (2007).

${ }^{75}$ Sharon Bessell. "Influencing international child labour policy: The potential and limits of children-centred research." Children and Youth Services Review 33, no. 4: 564-568, 567 (2011).

${ }^{76}$ Eric V.Ed monds and Nina Pavcnik. "Child labor in the global economy." Journal of Economic Perspectives: 19, no. 1:199-220 (2005).

${ }^{77}$ David P. Forsythe (ed.). Human Rights and. Comparative Foreign Policy: Foundations of Peace. Tokyo: United Nations University (2000).

${ }^{78}$ Engle Merry (2006), cit.; Simmons (2009), cit.

${ }^{79}$ Grugel and Peruzzotti (2010 and 2012), cit.

${ }^{80}$ See also Simmons (2009), cit. 